\title{
OPTIMASI BIAYA DISTRIBUSI BERAS MISKIN (RASKIN) MENGGUNAKAN MASALAH TRANSPORTASI TAK SEIMBANG
}

\section{Optimization on Costs of Poor Rice (RASKIN) Distribution using Unbalanced Transportation Problems}

\author{
Venn Y. I. Ilwaru ${ }^{1 *}$, Yopi Andry Lesnussa ${ }^{2}$, Jesica Tentua ${ }^{3}$ \\ 1,2,3 Program Studi Matematika FMIPA Universitas Pattimura \\ Jln. Ir. M. Putuhena, Kampus Unpatti, Poka-Ambon, Kode Pos 97233, Indonesia \\ e-mail:1*vennilwaru007@gmail.com; 2yopi_a_lesnussa@yahoo.com ; 3 jesika@gmail.com
} Corresponding author*

\begin{abstract}
Abstrak
Beras merupakan bahan makanan pokok sebagaian besar penduduk Indonesia. Seiring dengan bertambahnya jumlah penduduk kebutuhan beras pun meningkat. Pendistribusian beras merupakan hal yang sangat penting dalam hal efisiensi anggaran dan waktu. Tujuan penelitian ini adalah untuk meminimumkan hasil biaya distribusi beras miskin (RASKIN) dengan menggunakan metode modifikasi ASM (Abdul, Shaleh, Maliki) sehingga biaya distribusi yang diperoleh optimal. Penelitian ini dilakukan pada Perum BULOG Ambon Sub Divre Maluku. Berdasarkan hasil penelitian menunjukkan bahwa dengan menggunakan metode modifikasi ASM diperoleh biaya distribusi yang dikeluarkan oleh Perum BULOG Ambon Sub Divre Maluku sebesar Rp. 1.091.121.022.
\end{abstract}

Kata Kunci : Metode modifikasi ASM, distribusi RASKIN, biaya optimal

Abstract

Rice is the staple food for the majority of Indonesian population. As the population increases, the need for rice also increases. Rice distribution is very important in terms of budget and time efficiency. The purpose of this research was to minimize the distribution costs of poor rice (RASKIN) by using the ASM (Abdul, Shaleh, Maliki) modification method, so that the distribution costs obtained were optimal. This research was conducted at Perum BULOG Ambon Sub Divre Maluku. Based on the research results, it shows that by using the ASM modification method the distribution costs incurred by Perum BULOG Ambon Sub Divre Maluku is Rp. 1,091,121,022.

Keywords: ASM modification method, RASKIN distribution, optimal cost 


\section{PENDAHULUAN}

Beras merupakan bahan makanan pokok sebagaian besar penduduk Indonesia. Seiring dengan bertambahnya jumlah penduduk kebutuhan beras pun meningkat. RASKIN merupakan subsidi pangan dalam bentuk beras yang peruntukkan bagi rumah tangga berpenghasilan rendah sebagai upaya dari pemerintah untuk meningkatkan ketahanan pangan dan memberikan perlindungan sosial pada rumah tangga sasaran [1]. Tim Nasional Percepatan Penanggulangan Kemiskinan (TNP2K) dalam pelaksanaannya memiliki tim koordinasi yang terdiri dari beberapa lembaga negara dimana salah satunya Perum BULOG Sub Divre Maluku dan Maluku Utara.

Metode Transportasi dirancang untuk melakukan optimalisasi variabel yang digunakan dalam memecahkan masalah transportasi, termasuk di dalamnya masalah pengiriman barang dari beberapa sumber ke beberapa tujuan dengan tetap berorientasi pada biaya minimum, yakni setiap sumber mempunyai kapasitas tertentu dan setiap tujuan mempunyai permintaan tertentu. Seiring perkembangan, metode untuk mencari solusi masalah transportasi menjadi beragam, mulai dari metode mencari solusi fisibel awal, yaitu metode Pojok Barat Laut, metode Biaya Terkecil, dan metode VAM dengan dilanjutkan mencari solusi optimal akhir menggunakan metode Stepping Stone atau metode MODI [2]-[4]. Dengan berkembangnya ilmu pengetahuan di bidang riset operasional khususnya pada permasalahan transportasi maka munculah metode-metode langsung tanpa harus mencari solusi fisibel awal diantaranya metode Zero Suffix [5], metode Zero Point [6], metode Zero Neighbouring [7] dan sebagainya. Pada masalah transportasi yang harus diperhatikan adalah bahwa total kuantitas pada seluruh sumber harus sama dengan total kuantitas pada seluruh tujuan, dengan kata lain harus seimbang, jika tak seimbang maka perlu ditambahkan kuantitas dummy [8]. Berdasarkan perihal di atas maka metode modifikasi ASM dapat menyelesaikan permasalahan transportasi tak seimbang, sehingga tujuan penelitian ini untuk meminimumkan hasil biaya distribusi beras miskin (RASKIN) dengan menggunakan metode modifikasi ASM yang dapat menghasilkan solusi optimal pada masalah transportasi tak seimbang. Metode ASM pertama kali diperkenalkan oleh Abdul Quddoos, Shakeel Javaid, dan Mohd Masood Khalid [9]. Kemudian pada tahun 2016 dikembangkan menjadi metode modifikasi ASM yang mampu menyelesaikan masalah transportasi tidak seimbang [10]. Metode modifikasi ASM merupakan metode dengan proses yang sederhana tetapi menghasilkan biaya transportasi yang minimum tanpa menggunakan solusi awal dalam penyelesaiannya [11].

Beberapa penelitian terkait sebelumnya sudah dikemukakan diantaranya adalah kajian tentang minimisasi biaya distribusi RASKIN dengan metode Pojok Barat Laut (North West Corner) [12], optimasi biaya distribusi beras RASKIN pada perum bulog Ambon dengan menggunakan metode VAM [13], metode Perbaikan ASM pada masalah transportasi tak seimbang [14] dan optimasi transportasi tak seimbang menggunakan modifikasi metode ASM [15]. Dengan demikian, penelitian ini bertujuan untuk menghitung biaya distribusi RASKIN optimal dari Gudang Perum Bulog Ambon Sub Divre Maluku ke beberapa tujuan.

\section{METODE PENELITIAN}

Penelitian ini bersifat studi kasus pada Perum BULOG Ambon Sub Divre Maluku dengan data yang digunakan adalah data pendistribusian beras RASKIN ke kecamatan-kecamatan yang berada di Pulau Ambon. Metode yang digunakan adalah metode revisi ASM (Abdul, Shaleh, Maliki). Berikut adalah langkahlangkah penyelesaian dengan menggunakan metode modifikasi ASM [15]:

1. Mengamati keseimbangan masalah transportasi;

Dengan melihat teori keseimbangan, maka kita bisa menentukan apakah masalah transportasi tersebut seimbang atau tak seimbang.

2. Membentuk tabel transportasi seimbang;

Membentuk tabel transportasi seimbang dengan dengan cara menambahkan kolom dummy atau baris dummy dengan biaya awal 0 .

3. Reduksi tabel transportasi dengan dummy;

a) Jika pada tabel transportasi, baris dummy yang ditambahkan, maka dilanjutkan ke langkah ke-4. Langkah selanjutnya adalah mengganti biaya pada baris dummy dari hasil reduksi baris dengan biaya terbesar. Selanjutnya ke langkah ke-5 kemudian langkah ke-4. 
b) Jika pada tabel transportasi, kolom dummy yang ditambahkan, maka dilanjutkan ke langkah ke5. Langkah selanjutnya adalah mengganti biaya pada kolom dummy dari hasil reduksi kolom dengan biaya terbesar. Selanjutnya ke langkah ke-4 kemudian langkah ke-5.

4. Reduksi baris;

Setiap entri baris dikurangi dengan masing-masing biaya terkecilnya, yaitu $c_{i j}-u_{i}$.

5. Reduksi kolom;

Setiap entri kolom dikurangi dengan masing-masing biaya terkecilnya, yaitu $c_{i j}-u_{i}-v_{j}$.

6. Penetapan indeks;

Penetapan indeks $e$ dilakukan untuk setiap sel $i j$ yang bernilai 0 , dimana indeks $e$ merupakan banyaknya angka 0 pada baris ke- $i$ dan kolom ke- $j$ dan tidak termasuk angka 0 yang terpilih pada sel$i j$.

7. Pengalokasian;

Pilihlah angka 0 dengan indeks $e$ terkecil dan mengalokasikan sel dengan jumlah terbesar yang mungkin dengan melihat persediaan dan permintaan sel yang bersangkutan. Jika pada tabel terdapat indeks $e$ terkecil yang sama, maka selanjutnya dihitung masing-masing jumlah $c_{i j}=c_{i j}-u_{i}-v_{j}$ pada baris ke- $i$ dan kolom ke- $j$ dari sel-ij yang memiliki indeks $e$ terkecil yang sama dan alokasikanlah sebesar mungkin pada sel dengan hasil penjumlahan terbesar. Jika masih terjadi kesamaan, maka pilihlah sel-ij yang memiliki indeks $e$ terkecil yang sama dengan rata-rata persediaan dan permintaan terkecil.

8. Perbaikan tabel transportasi;

Untuk proses perhitungan selanjutnya, buatlah tabel transportasi baru dengan mengabaikan baris atau kolom yang permintaan atau persediaannya telah terpenuhi. Mengecek apakah tabel transportasi baru memiliki paling sedikit satu angka 0 pada setiap baris dan kolom. Jika tidak terdapat, kembali ke langkah ke-4.

9. Mengulangi langkah ke-6 sampai langkah ke-8 sampai semua permintaan terpenuhi dan semua persediaan habis.

Masalah umum transportasi dipresentasikan oleh Gambar 1, berikut [15] :

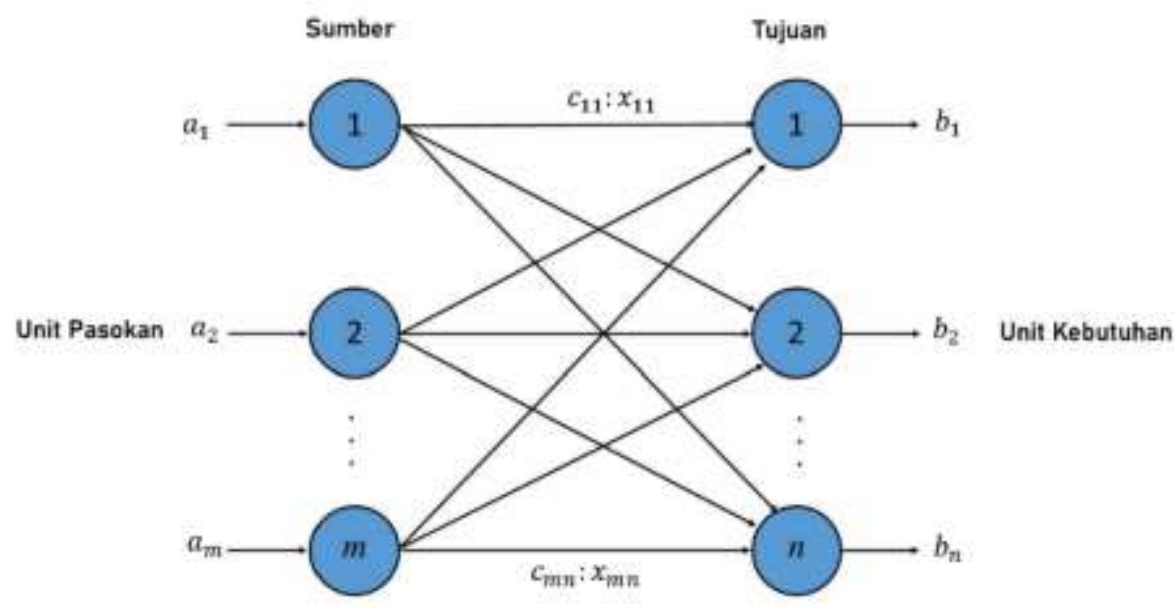

Gambar 1. Masalah Umum Transportasi

Dari Gambar 1, permasalahan transportasi disusun dalam Tabel 1 berikut ini [16]: 
Tabel 1. Masalah transportasi

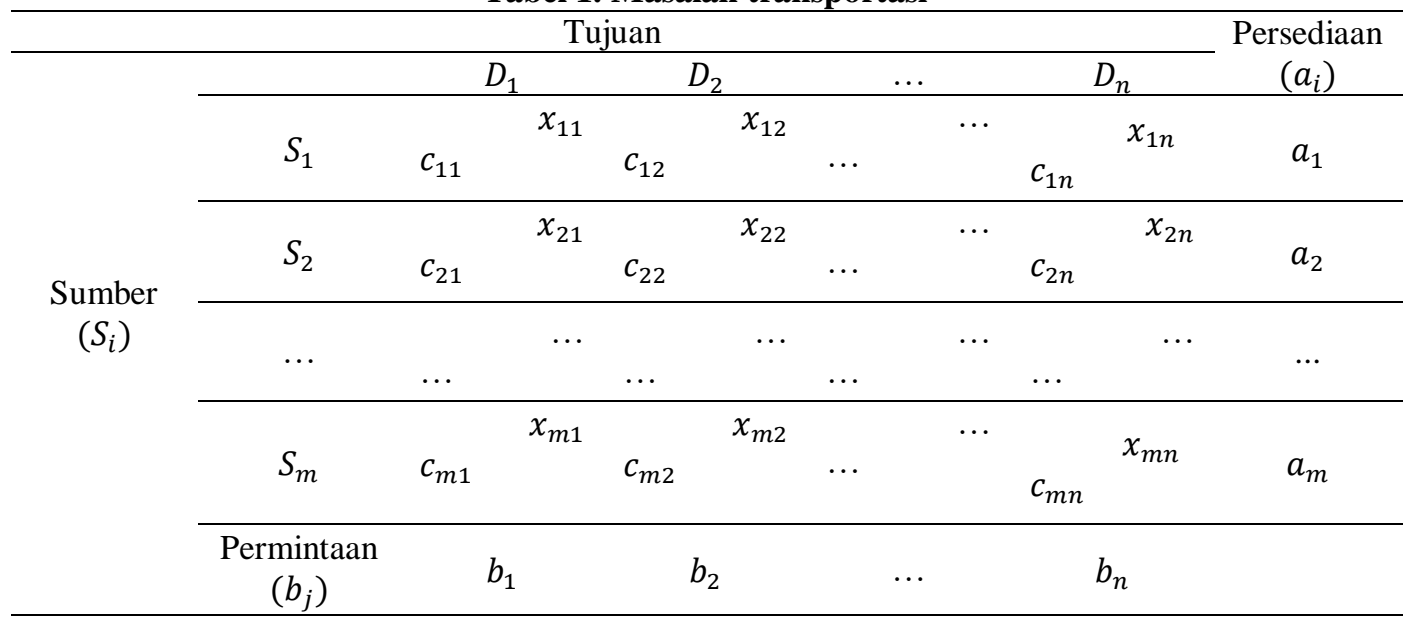

Keterangan :

$S_{i}$ : sumber ke-i, $i=1,2, \ldots, m$

$D_{j}$ : tujuan ke- $j, j=1,2, \ldots, n$

$a_{i}:$ persediaan ke- $i, i=1,2, \ldots, m$

$b_{j}:$ permintaan ke- $j, j=1,2, \ldots, n$

$C_{i j}$ : biaya transportasi barang dari sumber $i$ ke tujuan $j$, dengan $i=1,2, \ldots, m$ dan $j=1,2, \ldots, n$

$x_{i j}$ : banyak barang yang diangkut dari sumber $i$ ke tujuan $j, i=1,2, \ldots, m$ dan $j=1,2, \ldots, n$

Secara matematis, masalah ini dapat dinyatakan sebagai [15]:

$$
\begin{aligned}
\operatorname{Minimum} Z & =\sum_{i=1}^{m} \sum_{j=1}^{n} c_{i j} x_{i j} \\
& ={ }_{11} x_{11}+\cdots+c_{m n} x_{m n}
\end{aligned}
$$

Bergantung pada

$\sum_{j=1}^{n} x_{i j}=a_{i}, \quad i=1,2, \ldots, m$

$\sum_{i=1}^{m} x_{i j}=b_{j}, \quad j=1,2, \ldots, n$

$x_{i j} \geq 0 \quad \forall_{i, j}$

Pengumpulan data jumlah persediaan RASKIN di gudang yang berada di pulau Ambon pada bulan Januari tahun 2017, Jumlah Penyaluran RASKIN bulan Januari 2017, dan tarif angkut dari gudang ke titik distribusi. Data-data tersebut dapat dilihat pada Tabel 2, Tabel 3 dan Tabel 4 berikut:

Tabel 2. Persediaan RASKIN Bulan Januari Tahun 2017

\begin{tabular}{cclc}
\hline No. & Gudang & \multicolumn{1}{c}{ Lokasi } & Total Persediaan Beras (kg) \\
\hline 1 & G. Salobar & Air Salobar & 1.332 .634 \\
\hline 2 & G. Halong & Halong & 1.461 .624 \\
\hline 3 & G. Tulehu & Tulehu & 825.795 \\
\hline
\end{tabular}

Sumber: Perum BULOG Sub Divre Maluku 2017 
Tabel 3. Penyaluran RASKIN Bulan Januari Tahun 2017

\begin{tabular}{clc}
\hline No. & \multicolumn{1}{c}{ Titik Distribusi } & Jumlah Permintaan Beras (kg) / Tahun \\
\hline 1 & Kec. Nusaniwe & 603.900 \\
\hline 2 & Kec. Sirimau & 630.000 \\
\hline 3 & Kec. Teluk Ambon & 369.540 \\
\hline 4 & Kec. Baguala & 313.740 \\
\hline 5 & Kec. Leitimur Selatan & 110.520 \\
\hline 6 & Kec. Leihitu & 599.400 \\
\hline 7 & Kec. Leihitu Barat & 250.560 \\
\hline 8 & Kec. Salahutu & 351.540
\end{tabular}

Sumber: Perum BULOG Sub Divre Maluku 2017

Tabel 4. Tarif Angkut RASKIN dari Gudang ke titik Distribusi (Rp/kg)

\begin{tabular}{lcccccccc}
\hline \multicolumn{1}{c}{ Dari/Ke } & K. NS & K. SR & K. TA & K. BG & K. LS & K. LH & K. LB & K. SL \\
\hline GBB Salobar & 330 & 332 & 340 & 340 & 345 & 355 & 355 & 350 \\
\hline GBB Halong & 340 & 335 & 338 & 330 & 348 & 352 & 352 & 345 \\
\hline GSP Tulehu & 350 & 345 & 345 & 340 & 350 & 358 & 358 & 331 \\
\hline
\end{tabular}

Keterangan:

$\begin{array}{ll}\text { K.NS } & \text { : Kecamatan Nusaniwe } \\ \text { K.SR } & \text { : Kecamatan Sirimau } \\ \text { K.TA } & \text { : Kecamatan Teluk Ambon } \\ \text { K.BG } & \text { : Kecamatan Baguala }\end{array}$

K. LS : Kecamatan Leitimur Selatan

K.LH : Kecamatan Leihitu

K.LB : Kecamatan Leihitu Barat

K.BG : Kecamatan Baguala

K.SL : Kecamatan Salahutu

Data yang diperoleh kemudian diformulasikan ke dalam bentuk umum masalah transportasi sebagai berikut:

$$
\begin{aligned}
& \text { Minimum } Z=\sum_{i=1}^{m} \sum_{j=1}^{n} C_{i j} X_{i j} \\
& Z= 330 X_{11}+332 X_{12}+340 X_{13}+340 X_{14}+345 X_{15}+355 X_{16}+355 X_{17} \\
&+350 X_{18}+340 X_{21}+335 X_{22}+338 X_{23}+330 X_{24}+348 X_{25}+352 X_{26} \\
&+352 X_{27}+345 X_{28}+350 X_{31}+345 X_{32}+345 X_{33}+340 X_{34}+ \\
& 350 X_{35}+358 X_{36}+358 X_{37}+331 X_{38}
\end{aligned}
$$

Dengan fungsi batasan :

$$
\text { Penawaran: } \begin{aligned}
& X_{11}+X_{12}+X_{13}+X_{14}+X_{15}+X_{16}+X_{17}+X_{18}=1.332 .634 \\
& X_{21}+X_{22}+X_{23}+X_{24}+X_{25}+X_{26}+X_{27}+X_{28}=1.461 .624 \\
& X_{31}+X_{32}+X_{33}+X_{34}+X_{35}+X_{36}+X_{37}+X_{38}=825.795
\end{aligned}
$$

Permintaan: $X_{11}+X_{21}+X_{31}=603.900$

$X_{12}+X_{22}+X_{32}=630.000$

$X_{13}+X_{23}+X_{33}=369.540$

$X_{14}+X_{24}+X_{34}=313.740$

$X_{15}+X_{25}+X_{35}=110.520$

$X_{16}+X_{26}+X_{36}=599.400$

$X_{17}+X_{27}+X_{37}=250.560$

$X_{18}+X_{28}+X_{38}=351.540$

\section{HASIL DAN PEMBAHASAN}

Masalah transportasi dalam penelitian ini merupakan masalah transportasi tidak seimbang. Oleh karena itu, kita perlu menambahkan kolom dummy untuk membuat masalah dari transportasi tidak seimbang menjadi transportasi seimbang. Terdapat jumlah persediaan $\left(\sum a_{i}\right)=3.620 .053$ dan jumlah permintaan $\left(\sum b_{j}\right)=$ 3.229.200 maka diperoleh $\sum a_{i}>\sum b_{j}$, sehingga dibuat suatu tujuan kolom dummy untuk menyerap kelebihan tersebut yaitu sebesar $\sum a_{i}-\sum b_{j}=3.620 .053-3.229 .200=390.853$ maka diperoleh hasil sebagai berikut: 


\begin{tabular}{|c|c|c|c|c|c|c|c|c|c|c|}
\hline Tujuan & & & & Biaya & Angkut (F & p/kg) & & & & Persediaan \\
\hline Gudang & K.NS & K.SR & K.TA & K.BG & K.LS & K.LH & K.LB & K.SL & Dummy & \\
\hline & 330 & 332 & 340 & 340 & 345 & 355 & 355 & 350 & 0 & \\
\hline Salobar & $X_{11}$ & $X_{12}$ & $X_{13}$ & $X_{14}$ & $X_{15}$ & $X_{16}$ & $X_{17}$ & $X_{18}$ & $X_{19}$ & 1.352 .634 \\
\hline Halono & 340 & 335 & 338 & 330 & 348 & 352 & 352 & 345 & 0 & \\
\hline & $X_{21}$ & $X_{22}$ & $X_{23}$ & $X_{24}$ & $X_{25}$ & $X_{26}$ & $X_{27}$ & $X_{28}$ & $X_{29}$ & \\
\hline & 350 & 354 & 345 & 340 & 350 & 358 & 358 & 331 & 0 & \\
\hline Tulehu & $X_{31}$ & $X_{32}$ & $X_{33}$ & $X_{34}$ & $X_{35}$ & $X_{36}$ & $X_{37}$ & $X_{38}$ & $X_{39}$ & \\
\hline Permintaan & 603.900 & 630.000 & 369.540 & 313.740 & 110.520 & 599.400 & 250.560 & 351.540 & 390.853 & 3.620 .053 \\
\hline
\end{tabular}

Diketahui bahwa terjadi penambahan kolom dummy sehingga dilakukan reduksi kolom dengan mengurangi setiap entri kolom dengan masing-masing biaya terkecilnya. Pada kolom dummy yang ditambahkan, setiap entri kolom tetap bernilai 0. Maka diperoleh hasil sebagai berikut:

Tabel 6. Hasil Reduksi Kolom

\begin{tabular}{ccccccccccc}
\hline & $\boldsymbol{D}_{\mathbf{1}}$ & $\boldsymbol{D}_{\mathbf{2}}$ & $\boldsymbol{D}_{\mathbf{3}}$ & $\boldsymbol{D}_{\mathbf{4}}$ & $\boldsymbol{D}_{\mathbf{5}}$ & $\boldsymbol{D}_{\mathbf{6}}$ & $\boldsymbol{D}_{\mathbf{7}}$ & $\boldsymbol{D}_{\mathbf{8}}$ & Dummy & Persediaan \\
\hline $\boldsymbol{S}_{\mathbf{1}}$ & 0 & 0 & 2 & 10 & 0 & 3 & 3 & 19 & 0 & 1.332 .634 \\
\hline $\boldsymbol{S}_{\mathbf{2}}$ & 10 & 3 & 0 & 0 & 3 & 0 & 0 & 14 & 0 & 1.461 .624 \\
\hline $\boldsymbol{S}_{\mathbf{3}}$ & 20 & 13 & 7 & 10 & 5 & 6 & 6 & 0 & 0 & 825.795 \\
\hline Permintaan & 603.900 & 630.000 & 369.540 & 313.740 & 110.520 & 599.400 & 250.560 & 351.340 & 390.853 & 3.620 .053 \\
\hline
\end{tabular}

Selanjutnya dilakukan penggantian nilai dummy dengan nilai tereduksi kolom terbesar. Dari hasil reduksi kolom pada Tabel 6, diperoleh nilai tereduksi terbesar pada setiap entri kolom yaitu 20, sehingga diperoleh hasil sebagai berikut:

Tabel 7. Penggantian nilai Dummy

\begin{tabular}{ccccccccccc}
\hline & $\boldsymbol{D}_{\mathbf{1}}$ & $\boldsymbol{D}_{\mathbf{2}}$ & $\boldsymbol{D}_{\mathbf{3}}$ & $\boldsymbol{D}_{\mathbf{4}}$ & $\boldsymbol{D}_{\mathbf{5}}$ & $\boldsymbol{D}_{\mathbf{6}}$ & $\boldsymbol{D}_{\mathbf{7}}$ & $\boldsymbol{D}_{\mathbf{8}}$ & $\begin{array}{c}\text { Dummy } \\
\text { Persediaa } \\
\mathbf{n}\end{array}$ \\
\hline $\boldsymbol{S}_{\mathbf{1}}$ & 0 & 0 & 2 & 10 & 0 & 3 & 3 & 19 & 20 & 1.332 .634 \\
\hline $\boldsymbol{S}_{\mathbf{2}}$ & 10 & 3 & 0 & 0 & 3 & 0 & 0 & 14 & 20 & 1.461 .624 \\
\hline $\boldsymbol{S}_{\mathbf{3}}$ & 20 & 13 & 12 & 10 & 5 & 6 & 6 & 0 & 20 & 825.795 \\
\hline Permintaan & 603.900 & 630.000 & 369.540 & 313.740 & 110.520 & 599.400 & 250.560 & 351.340 & 390.853 & 3.620 .053 \\
\hline
\end{tabular}

Selanjutnya dilakukan reduksi baris dengan mengurangi setiap entri baris dengan masing-masing biaya terkecilnya sehingga diperoleh hasil sebagai berikut:

Tabel 8. Hasil Reduksi Baris

\begin{tabular}{ccccccccccc}
\hline & $\boldsymbol{D}_{\mathbf{1}}$ & $\boldsymbol{D}_{\mathbf{2}}$ & $\boldsymbol{D}_{\mathbf{3}}$ & $\boldsymbol{D}_{\mathbf{4}}$ & $\boldsymbol{D}_{\mathbf{5}}$ & $\boldsymbol{D}_{\mathbf{6}}$ & $\boldsymbol{D}_{\mathbf{7}}$ & $\boldsymbol{D}_{\mathbf{8}}$ & Dummy & Persediaan \\
\hline $\boldsymbol{S}_{\mathbf{1}}$ & 0 & 0 & 2 & 10 & 0 & 3 & 3 & 19 & 20 & 1.332 .634 \\
\hline $\boldsymbol{S}_{\mathbf{2}}$ & 10 & 3 & 0 & 0 & 3 & 0 & 0 & 14 & 20 & 1.461 .624 \\
\hline $\boldsymbol{S}_{\mathbf{3}}$ & 20 & 13 & 12 & 10 & 5 & 6 & 6 & 0 & 20 & 825.795 \\
\hline Permintaan & 603.900 & 630.000 & 369.540 & 313.740 & 110.520 & 599.400 & 250.560 & 351.340 & 390.853 & 3.620 .053 \\
\hline
\end{tabular}

Kembali dilakukan reduksi kolom agar setidaknya ada satu nol pada kolom dummy dengan mengurangi setiap entri kolom dengan masing-masing biaya terkecilnya sehingga diperoleh hasil sebagai berikut: 


\begin{tabular}{ccccccccccc}
\hline & $\boldsymbol{D}_{\mathbf{1}}$ & $\boldsymbol{D}_{\mathbf{2}}$ & $\boldsymbol{D}_{\mathbf{3}}$ & $\boldsymbol{D}_{\mathbf{4}}$ & $\boldsymbol{D}_{\mathbf{5}}$ & $\boldsymbol{D}_{\mathbf{6}}$ & $\boldsymbol{D}_{\mathbf{7}}$ & $\boldsymbol{D}_{\mathbf{8}}$ & Dummy & Persediaan \\
\hline $\boldsymbol{S}_{\mathbf{1}}$ & 0 & 0 & 2 & 10 & 0 & 3 & 3 & 19 & 0 & 1.332 .634 \\
\hline $\boldsymbol{S}_{\mathbf{2}}$ & 10 & 3 & 0 & 0 & 3 & 0 & 0 & 14 & 0 & 1.461 .624 \\
\hline $\boldsymbol{S}_{\mathbf{3}}$ & 20 & 13 & 7 & 10 & 5 & 6 & 6 & 0 & 0 & 825.795 \\
\hline Permintaan & 603.900 & 630.000 & 369.540 & 313.740 & 110.520 & 599.400 & 250.560 & 351.340 & 390.853 & 3.620 .053 \\
\hline
\end{tabular}

Selanjutnya, pada Tabel 9 terlihat bahwa dapat dilakukan penetapan indeks $e$ untuk setiap sel $i j$ yang bernilai nol dimana indeks $e$ adalah banyaknya angka 0 pada baris ke- $i$ dan kolom ke- $j$. Maka diperoleh Tabel 10 berikut:

Tabel 10. Penetapan Indeks

\begin{tabular}{ccccccccccc}
\hline & $\boldsymbol{D}_{\mathbf{1}}$ & $\boldsymbol{D}_{\mathbf{2}}$ & $\boldsymbol{D}_{\mathbf{3}}$ & $\boldsymbol{D}_{\mathbf{4}}$ & $\boldsymbol{D}_{\mathbf{5}}$ & $\boldsymbol{D}_{\mathbf{6}}$ & $\boldsymbol{D}_{\mathbf{7}}$ & $\boldsymbol{D}_{\mathbf{8}}$ & Dummy & Persediaan \\
\hline $\boldsymbol{S}_{\mathbf{1}}$ & $0_{1}$ & $0_{2}$ & $2_{1}$ & 10 & $0_{4}$ & 3 & 3 & 19 & $0_{3}$ & 1.332 .63 \\
\hline $\boldsymbol{S}_{\mathbf{2}}$ & 10 & 3 & $0_{2}$ & $0_{3}$ & 3 & $0_{4}$ & $0_{5}$ & 14 & $0_{1}$ & 1.461 .62 \\
\hline $\boldsymbol{S}_{\mathbf{3}}$ & 20 & 13 & 7 & 10 & $5_{1}$ & 6 & 6 & $0_{1}$ & $0_{2}$ & 825.79 \\
\hline Permintaan & 603.90 & 630.00 & 369.54 & 313.74 & 110.52 & 599.40 & 250.56 & 351.34 & 390.85 & 3.620 .05 \\
\hline
\end{tabular}

Selanjutnya, pada Tabel 10 dilakukan pengalokasikan dengan cara memilih angka 0 dengan indeks $e$ terkecil dan mengalokasikan sel dengan jumlah terbesar yang mungkin dengan melihat persediaan dan permintaan sel yang bersangkutan sampai permintaan dan persediaan terpenuhi. Diperoleh indeks terkecil pertama pada sel $\left(S_{3}, D_{8}\right)$ artinya bahwa gudang Tulehu mempunyai indeks terkecil yang paling pertama pada kecamatan Salahutu dan dapat diperlihatkan pada Tabel 11 berikut ini:

Tabel 11. Pengalokasikan Ke Indeks Terkecil

\begin{tabular}{ccccccccccc}
\hline & $\boldsymbol{D}_{\mathbf{1}}$ & $\boldsymbol{D}_{\mathbf{2}}$ & $\boldsymbol{D}_{\mathbf{3}}$ & $\boldsymbol{D}_{\mathbf{4}}$ & $\boldsymbol{D}_{\mathbf{5}}$ & $\boldsymbol{D}_{\mathbf{6}}$ & $\boldsymbol{D}_{\mathbf{7}}$ & $\boldsymbol{D}_{\mathbf{8}}$ & Dummy & Persediaan \\
\hline $\boldsymbol{S}_{\mathbf{1}}$ & $0_{1}$ & $0_{2}$ & $2_{1}$ & 10 & $0_{4}$ & 3 & 3 & 19 & $0_{3}$ & 1.332 .634 \\
\hline $\boldsymbol{S}_{\mathbf{2}}$ & 10 & 3 & $0_{2}$ & $0_{3}$ & 3 & $0_{4}$ & $0_{5}$ & 14 & $0_{1}$ & 1.461 .624 \\
\hline $\boldsymbol{S}_{\mathbf{3}}$ & 20 & 13 & 7 & 10 & $5_{1}$ & 6 & 6 & $0_{1}$ & $0_{2}$ & 825.795 \\
\hline Permintaan & 603.900 & 630.000 & 369.540 & 313.740 & 110.520 & 599.400 & 250.560 & 351.340 & 390.853 & 3.620 .053 \\
\hline
\end{tabular}

Pada Tabel 11 diketahui indeks terkecil pertama terdapat pada sel $\left(S_{3}, D_{8}\right)$ dan dilakukan pengalokasian ke sel yang memiliki nilai indeks terkecil pada kolom yang terpilih. Dalam hal ini sel $C_{38}$ memiliki nilai $C_{i j}$ terkecil, maka alokasi atau distribusi maksimum sebesar $351.340 \mathrm{~kg}$, sehingga dilakukan untuk memenuhi permintaan beras raskin pada kolom $D_{8}$ atau pada Kecamatan Salahutu yang didistribusikan dari Gudang Tulehu. Karena masih ada kecamatan yang permintaanya belum terpenuhi, sehingga persediaan pada baris $S_{3}$ atau pada Gudang Tulehu bersisa $474.255 \mathrm{~kg}$, maka proses perhitungan selanjutnya dilakukan penetapan indeks kembali pada sel $C_{39}\left(S_{3}\right.$, Dummy $)$ dan diperoleh Tabel 12 berikut:

Tabel 12. Pengalokasian

\begin{tabular}{ccccccccccc}
\hline & $\boldsymbol{D}_{\mathbf{1}}$ & $\boldsymbol{D}_{\mathbf{2}}$ & $\boldsymbol{D}_{\mathbf{3}}$ & $\boldsymbol{D}_{\mathbf{4}}$ & $\boldsymbol{D}_{\mathbf{5}}$ & $\boldsymbol{D}_{\mathbf{6}}$ & $\boldsymbol{D}_{\mathbf{7}}$ & $\boldsymbol{D}_{\mathbf{8}}$ & Dummy & Persediaan \\
\hline $\boldsymbol{S}_{\mathbf{1}}$ & $0_{1}$ & $0_{2}$ & $2_{1}$ & 10 & $0_{4}$ & 3 & 3 & & $0_{3}$ & 1.332 .634 \\
\hline $\boldsymbol{S}_{\mathbf{2}}$ & 10 & 3 & $0_{2}$ & $0_{3}$ & 3 & $0_{4}$ & $0_{5}$ & & $0_{1}$ & 1.461 .624 \\
\hline $\boldsymbol{S}_{\mathbf{3}}$ & 20 & 13 & 7 & 10 & $5_{1}$ & 6 & 6 & 351.340 & $0_{1}$ & 474.255 \\
\hline Permintaan & 603.900 & 630.000 & 369.540 & 313.740 & 110.520 & 599.400 & 250.560 & 0 & 390.853 & 3.620 .053 \\
\hline
\end{tabular}

Pada Tabel 12 diketahui indeks terkecil pertama terdapat pada sel $C_{39}\left(S_{3}\right.$, Dummy $)$ dan dilakukan pengalokasian permintaan berjumlah 390.853, sehingga permintaan pada kolom Dummy terpenuhi dan persediaan pada bari $S_{3}$, bersisa 83.402. Selanjutnya dilakukan penetapan indeks kembali sampai semua permintaan dan persediaan dialokasikan. Berikut adalah hasil penyelesaian dengan menggunakan metode modifikasi ASM. 


\begin{tabular}{|c|c|c|c|c|c|c|c|c|c|c|}
\hline \multirow{2}{*}{$\begin{array}{r}\text { Tujuan } \\
\text { Gudang }\end{array}$} & \multicolumn{9}{|c|}{ Biaya Angkut (Rp/Kg) } & \multirow{2}{*}{ Persediaan } \\
\hline & K.NS & K.SR & K.TA & K.BG & K.LS & K.LH & K.LB & K.SL & Dummy & \\
\hline & 330 & 332 & 340 & 340 & 345 & 355 & 355 & 350 & 0 & \multirow[b]{2}{*}{0} \\
\hline Salobar & 603.900 & 630.000 & 71.616 & & 27.118 & & & & & \\
\hline Halong & 340 & 335 & 338 & 330 & 348 & 352 & 352 & 345 & 0 & \multirow{2}{*}{0} \\
\hline & & & 297.924 & 313.740 & & 599.400 & 250.560 & & & \\
\hline Tulehu & 350 & 354 & 345 & 340 & 350 & 358 & 358 & 331 & 0 & \\
\hline & & & & & 83.402 & & & 351.340 & 390.853 & 0 \\
\hline Permintaan & 0 & 0 & 0 & 0 & 0 & 0 & 0 & 0 & 0 & 3.620 .053 \\
\hline
\end{tabular}

Berdasarkan Tabel 13 bahwa jumlah pendistribusian beras sudah memenuhi jumlah pada persediaan untuk setiap gudang, sehingga alokasi tersebut merupakan alokasi terakhir yang merupakan penyelesaian masalah transportasi tak seimbang tersebut. Dari hasil tersebut maka dapat dirangkum menjadi:

Tabel 14. Alokasi optimal dengan menggunakan metode modifikasi ASM SUMBER TITIK DISTRIBUSI BERAS DISTRIBUSI

\begin{tabular}{lll}
\hline \multirow{2}{*}{ G. SALABOR } & \multicolumn{1}{c}{$(\mathbf{k g})$} \\
\cline { 2 - 3 } & Kec. Nusaniwe & 603.900 \\
\cline { 2 - 3 } & Kec. Sirimau & 630.000 \\
\hline \multirow{2}{*}{ G. HALONG } & Kec. Telumur Selatan & 110.520 \\
\cline { 2 - 3 } & Kec. Baguala & 369.540 \\
\cline { 2 - 3 } & Kec. Leihitu & 313.740 \\
\hline \multirow{2}{*}{ G. TULEHU } & Kec. Lehitu Barat & 599.400 \\
\cline { 2 - 3 } & Kec. Salahutu & 250.560 \\
\cline { 2 - 3 } & Dummy & 351.340 \\
\hline
\end{tabular}

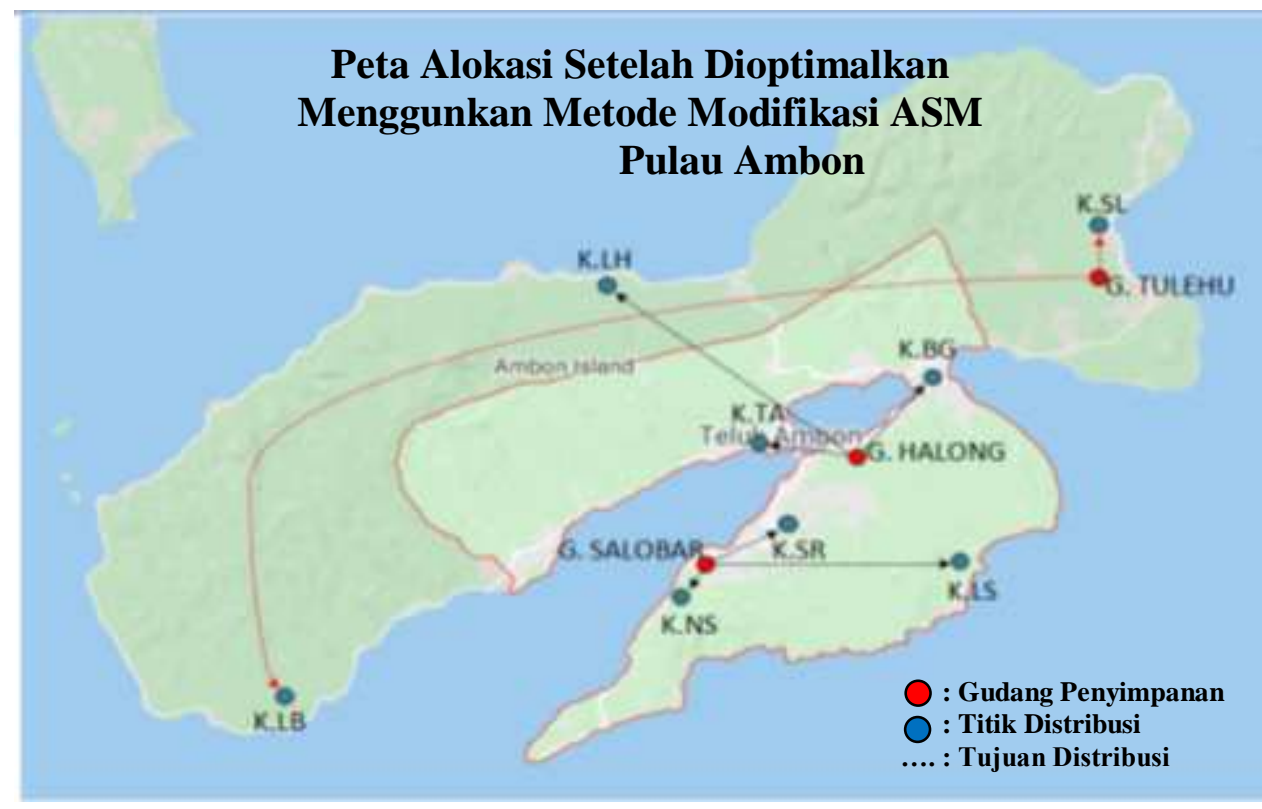

Gambar 2. Peta distribusi RASKIN dari gudang ke tujuan distribusi

Hasil alokasi RASKIN untuk mencari nilai optimal biaya distribusi beras miskin (RASKIN) dengan menggunakan metode ASM di bawah ini: 


$$
\begin{aligned}
Z=\sum_{i=1}^{m} \sum_{j=1}^{n} c_{i j} x_{i j}= & c_{11} x_{11}+c_{12} x_{12}+c_{13} x_{13}+c_{15} x_{15}+c_{23} x_{23}+ \\
& c_{24} x_{24}+c_{25} x_{25}+c_{26} x_{26}+c_{35} x_{35}+c_{38} x_{38}+c_{39} x_{39} \\
= & (330)(603.900)+(332)(630.000)+(340)(71.616) \\
& +(345)(27.118)+(338)(297.924)+(330)(313.740) \\
& +(352)(599.400)+(352)(250.560)+(350)(83.402) \\
& +(331)(351.340)+(0)(390.853) \\
= & 199.287 .000+209.160 .000+24.349 .4+9.355 .710 \\
& +100.698 .312+103.534 .200+210.988 .800 \\
& +88.197 .120+29.190 .700+116.359 .740 \\
= & 1.091 .121 .022
\end{aligned}
$$

Jadi, total biaya distribusi RASKIN untuk memenuhi permintaan semua kecamatan di Pulau Ambon dengan menggunakan metode ASM adalah sebesar Rp. 1.091.121.022.

\section{KESIMPULAN}

Berdasarkan hasil penelitian maka dapat disimpulkan bahwa metode modifikasi ASM (Abdul, Shaleh, Maliki) dapat digunakan sebagai alternatif metode untuk meminimumkan biaya masalah transportasi tak seimbang sehingga hasil yang diperoleh dapat memberikan solusi optimal. Metode Modifikasi ASM merupakan metode yang sederhana dan mudah diaplikasikan untuk berbagai permasalahan transportasi. Biaya yang dikeluarkan oleh Perum BULOG Ambon Sub Divre Maluku adalah sebesar Rp.1.091.121.022,00.

\section{DAFTAR PUSTAKA}

[1] N. W. Putu Artini and . J. D., "ANALISIS KEPUASAN RUMAH TANGGA PENERIMA RASKIN DI KABUPATEN TABANAN," J. Manaj. AGRIBISNIS (Journal Agribus. Manag., 2018, doi: 10.24843/jma.2018.v06.i02.p12.

[2] Siswanto, Operation Research. Jakarta: Erlangga, 2016.

[3] S. Bhaskar, "Operation research," Commun. Stat. Stoch. Model., 1986, doi: 10.1080/15326348608807035.

[4] A. Bhunia, L. Sahoo, and A. Shaikh, Advanced Optimization and Operations Research. 2019.

[5] S. Sharma, R. Shanker, and R. Shanker, "A Modified Zero Suffix Method for Finding an Optimal Solution for Transportation Problems," Eur. J. Sci. Res., vol. 104, pp. 673-676, 2013.

[6] A. Samuel, "Improved Zero Point Method (IZPM) for the Transportation Problems," Appl. Math. Sci., vol. 6, 2012.

[7] K. Thiagarajan and P. N. H.Saravanan, "Finding an Optimal Solution for Transportation Problem- Zero Neighbouring Method," Ultra Sci., vol. 25, no. 2, pp. 281-284, 2013.

[8] A. K. Bhunia, L. Sahoo, and A. A. Shaikh, "Introduction to Operations Research," in Springer Optimization and Its Applications, 2019.

[9] A. Quddos, S. Javaid, and M. M. Khalid, "A New Method for Finding an Optimal Solution for Transportation Problems," Int. J. Comput. Sci. Eng., 2012.

[10] A. Quddoos, S. Javaid, and M. M. Khalid, "A revised version of asm-method for solving transportation problem," Int. J. Agric. Stat. Sci., 2016.

[11] D. Basriati, Sri, Cahyani, "Penyelesaian Model Transportasi Menggunakan," J. Sains Mat. dan Stat., vol. 3, no. 2, pp. 67-73, 2017.

[12] I. M. Putri, B. Widada, and E. Rimawati, "Minimasi Biaya Distribusi Beras Miskin Dengan Metode North West Coner Pada Perum BULOG Subdivre III Surakarta," J. Ilm. SINUS, 2018, doi: 10.30646/sinus.v16i1.330.

[13] Y. A. Lesnussa, D. N. Noya, F. Kondo Lembang, and V. Y. I. Ilwaru, "Aplikasi Metode Transportasi Menggunakan VAM Dan MODI Untuk Optimasi Biaya Distribusi Beras Miskin (Raskin) Pada perum Bulog Ambon," in KNM XIX, 2018, p. 851.

[14] Solikhin, "Metode Perbaikan ASM pada Masalah Transportasi Tak Seimbang," in Seminar Matematika Dan Pendidikan Matematika UNY 2017, 2017, pp. 249-256.

[15] M. Nadhirah, "Optimasi Transportasi Tak Seimbang Dengan Menggunakan Modifikasi Metode ASM," Universitas Sumatra Utara, 2019.

[16] R. Patel, "On Optimal Solution of a Transportation Problem," Glob. J. Pure Appl. Math., 2017. 